\title{
RELASI PEKERJA SOSIAL DALAM PEMBINAAN ANAK JALANAN MELALUI RUMAH SINGGAH
}

\author{
Oleh \\ Dr. Firman.MS \\ (Dosen Fakultas Ilmu Pendidikan Univ. Negeri Padang) \\ Email : firman@konselor.org
}

\section{A. Pendahuluan.}

Laju urbanisasi yang begitu cepat serta krisis multi dimensi yang sedang dihadapi bangsa Indonesia, menimbulkan dampak yang cukup serius di segala bidang kehidupan masyarakat. Salah satu dampak yang cukup menonjol di perkotaan adalah semakin meningkatnya jumlah anak jalanan. Perkotaan Sumatera Barat di samping berfungsi sebagai pusat perekonomian dan juga pusat pemerintahan Daerah Tingkat I/ II, tidak luput dari masalah anak jalanan.

Berdasarkan hasil Pemetaan dan survei sosial anak jalanan di salah satu kota Sumatera Barat, yang dilaksanakan oleh Kanwil Depsos Propinsi Sumatera Barat bekerjasama dengan Pusat Kajian Pembangunan Masyarakat (PKPM) Universitas Kristen Atmajaya Jakarta pada bulan April 1999, ditemukan jumlah anak jalanan sebanyak 2.096 orang (Kanwil Depsos Sumbar, 1999:15). Keberadaan anak jalanan ditemui dipusat keramaian, diperempatan jalan utama dan sentra ekonomi lainnya Mereka bekerja di jalanan dengan alasan membantu biaya kehidupan keluarga, sekolah dan kepentingan diri sendiri.

Berbagai permasalahan dialami anak jalan dewasa ini, sebagai akibat kurangnya dukungan social dari orang tua, di samping pengaruh lingkungan membuat anak jalanan terjebak tindakan criminal, eksploitasi ekonomi, mengalami perlakuan 
yang salah dari berbagai pihak, seperti penyiksaan, sodomi, pemerkosaan dan ganguan penyakit. Selain itu, anak jalanan tidak dapat menjalani tugas-tugas perkembangannya, seperti anak lainnya karena pada usia tersebut seharusnya tidak mengerjakan pekerjaan yang bukan beban anak-anak. Mereka tidak mempunyai kesempatan bermain, mendapat kasih sayang serta bergaul dengan teman sebayanya.

Anak jalanan sebenarnya memiliki potensi yang belum berkembang secara maksimal untuk melepaskan dirinya dari himpitan ekonomi. Berbagai hak dan kebutuhan mereka belum terpenuhi, seperti makan dan gizi, kesehatan, bermain, pengembangan moral serta pendidikan. Keunggulan anak jalanan dibandingkan anak lainnya adalah gigih, mempunyai semangat yang pantang menyerah tidak mudah tersinggung dan inisiatif tinggi untuk memanfaatkan kekuatan sendiri dalam memenuhi kebutuhan hidup.

Persoalan anak jalanan akan berdampak negatif secara berantai apabila tidak ditanggani secara serius. Kehidupan anak jalanan penuh dengan kekerasan serta berpotensi untuk tubuhnya kriminalitas dan menjadi sasaran yang efektif penyebaran penyalahgunaan narkoba, yang pada gilirannya menganggu serta merusak stabilitas kehidupan masyarakat. Di sisi lain, berdasarkan penelitian Sandora (2003) ditemukan, anak jalanan menjadi masalah bukan saja karena mereka telah melakukan kegiatan ekonomi akan tetapi karena banyak menerima perlakuan salah (Child Abuse) dari keluarga, lingkungan tempat tinggal, serta sesama anak jalanan sendiri.

Selanjutnya Sandora (2003) mengungkapkan perlakuan salah yang dialami anak jalanan di Sumatera Barat dapat dikelompokkan, yaitu: perlakuan salah 
mengenai fisik, mental dan seksual. Perlakuan yang salah dialami anak jalanan di Sumatera Barat terlihat pada tabel berikut

Tabel 1.

Perlakuan Salah terhadap Anak Jalanan di Sumatera Barat.

\begin{tabular}{|c|c|c|c|c|c|c|}
\hline \multicolumn{7}{|c|}{ Pelaku } \\
\hline \multicolumn{2}{|c|}{ Oleh Orang Tua } & \multicolumn{2}{|c|}{ Oleh Teman Sesama Anjal } & \multicolumn{3}{|c|}{ Petugas dan Masyarakat } \\
\hline Fisik & Mental & Fisik & Mental & Fisik & Mental & Seksual \\
\hline Dipukul & Dipaksa & Dipukul & Saling mengejek & Dipukul & Dilecehkan & Dielus \\
\hline Ditampar & Tidak disayang & Ditampar & Ditipu & Ditampar & Dituduh & Dipeluk \\
\hline Diikat & Tidak diperhatikan & & Dipalak & $\begin{array}{l}\text { Keserempet } \\
\text { mobil/motor }\end{array}$ & Dihina & \\
\hline Tidak diberi makan & Dimarahi & & Dipaksa & Digeledah & Dihardik & \\
\hline Disuruh bekerja keras & dihardik & & Dilecehkan & & $\begin{array}{l}\text { Dianggap } \\
\text { sampah } \\
\text { masyarakat }\end{array}$ & \\
\hline
\end{tabular}

Kondisi tersebut membahayakan perkembangan anak jalanan dan lingkungannya. Berdasarkan pengamatan, anak jalanan telah melakukan prilaku menyimpang yang bisa membahayakan perkembangan mental maupun fisik mereka. Berdasarkan penelitian Saleh (Kanwil Depsos Prop. Sumbar, 1999:2) mengungkapkan anak jalanan cenderung melakukan tindakan pencurian dan meminum-minuman keras, sedangkan menurut Embrio (Kanwil Depsos Prop.Sumbar, 1999:2) ditemukan sebagian anak jalanan telah melakukan hubungan seks di luar nikah.

Menghadapi kondisi tersebut di atas, berbagai usaha telah dilakukan oleh pemerintah dan masyarakat demi mengatasi serta menanggulangi permasalahan anak 
jalanan, seperti yang pernah dilaksanakanpemerintah DKI Jakarta, anak jalanan di tempatkan pada sebuah rumah penampungan berjeruji besi dan dikunci dari luar yang bernama Panti Sosial Bina Karya Bangun Daya 01 Cipayung Jakarta Timur. Razia yang dilaksanakan oleh aparat kepolisian untuk menghalau pengemis termasuk anak jalanan juga merupakan tindakan yang dinilai tidak manusiawi.

Selanjutnya pola pembinaan pesantren yang dilaksanakan di Dusun Ploso Kuning, Condong Catur, Sleman, Yogyakarta, dengan mendirikan sebuah lembaga tempat anak-anak jalanan mendapatkan pendidikan dan keterampilan yang berada di bawah naungan Yayasan Humana yang bekerjasama dengan Yayasan Cakra Indonesia sebagai konsultan. Tenaga pendidik dikerahkan sebanyak 10 (sepuluh) orang. Struktur yang dipakai seperti struktur sebuah perguruan tinggi yang terdiri dari rektor, dosen dan mahasiswa. Karena itulah lembaga ini dinamakan oleh anak jalanan dengan istilah Kampus Tikyan yang artinya sitik-sitik lumayan, (meskipun hasilnya sedikit tapi lumayan).

Alternatif lain pembinaan terhadap anak jalanan yang dikelola secara swadaya oleh pihak swasta ataupun pemerintah, adalah melalui pendirian pondok pemberdayaan anak jalanan yang terkumpul pada suatu tempat yang dinamakan dengan istilah Rumah Singgah. Keberadaan rumah singgah dimaksudkan sebagai tempat berteduh dan memperoleh perlindungan agar dapat bertumbuh serta berkembang seperti anak lainnya.

Selama di rumah singgah berkumpulan anak jalanan dari berbagai latar belakang etnis, agama tanpa dibedakan satu sama lainnya. Melalui rumah singgah anak jalanan dapat bermain serta bercanda dengan sesama anak jalanan dan pekerja 
sosial. Keberadaan rumah singgah baru berkembang sejak tahun 1997 bersamaan dengan terjadinya krisis moneter. Pada tahap awal rumah singgah berfungsi untuk penangganan secara terarah terhadap anak jalanan. Pada tahap selanjutnya keberhasilan rumah singgah membina anak jalanan sangat ditentukan oleh program dan strategi yang digunakan di rumah singgah.

Berbagai potensi yang dimiliki anak jalanan dapat dimanfaatkan dalam upaya memandirikan mereka. Marnio Pudjono (Buletin JPS, 2002) menjelaskan sejumlah sikap-sikap yang terkait dengan keperibadian yang berkembang ditengah anak jalanan yang dapat dijadikan sebagai faktor positif pemberdayaan anak jalanan. Beberapa sikap tersebut adalah rasa solidaritas yang tinggi, adanya basis pemahaman agama, ekonomi dan lain sebagainya. Sikap solidaritas dan ekonomi dapat dikembangkan membangun usaha bersama yang mempunyai nilai ekonomi. Sementara sikap relgius dapat digunakan untuk pembinaan moral.

Pendampingan anak jalanan merupakan tahap yang paling penting sebagai proses awal dalam pemberdayaan. Nyadi (Bulittin Jaringan Pengamanan Sosial,2002:4) mengungkapkan setidaknya tedapat empat tahap yang dilewati dalam proses pendapingan di rumah singgah, yaitu ; (1) pekerja sosial (Peksos) menjalin pertemanan dengan anak jalanan di tempat mereka mangkal, (2) mengenal rumah singgah sebagai tempat berteduh untuk memperoleh perlindungan, (3) identifikasi anak jalanan tersebut, jika memiliki orang tua dan diupayakan untuk kebali kepada orang tua. Bagi anak usia sekolah diupayakan untuk kembali bersekolah, dan (4) bagi anak yang tidak sekolah dan berusia 14 tahun ke atas diupayakan mengikuti pendidikan latihan dengan bekal keahlian yang memadai. 
Salah satu contoh pembinaan anak jalanan di Kota Padang terdapat sebayak 24 (dua puluh empat) buah Rumah Singgah, dan 11 (sebelas) rumah singgah diantaranya mendapatkan bantuan dana dari HNSDP (health and Nutrition sector Development Programe) untuk anggaran tahun 1999/2000. Sedangkan untuk anggaran tahun 2004, pemerintah melalui dana APBN menyalurkan bantuan untuk pembinaan anak jalanan dalam rumah singgah sebanyak 12 (dua belas) rumah singgah.

Begitu banyak usaha yang telah dilakukan oleh pemerintah dan masyarakat dalam menanggulangi sarta membina anak jalanan. Akan tetapi fenomena anak jalanan makin lama makin kompleks, berdasarkan pengamatan ditemukan jumlah anak jalanan makin hari makin bertambah, perilaku anak jalanan juga semakin beragam bahkan pola kehidupan anak jalanan semakin bebas dan tidak terkontrol. Sewaktu proyek rumah singgah dicanangkan pemerintah daerah, beribu LSM/Yayasan berdiri dengan fokus kegiatan pembinaan terhadap anak. Setelah berakhirnya proyek, sebagian LSM/Yayasan yang membina rumah singgah tersebut hilang dari peredaran dan kegiatan pembinaan anak jalanan yang dibinanya terhenti serta tidak tahu hutan rimbanya.

Selama proses pembinaan anak jalanan yang dilakukan sebagian rumah singgah tidak jarang bermasalah, diantaranya : anak yang dibina tumpang tindih antar satu rumah singgah yang dibina LSM/Yayasan berdekatan. Sebagian anak-anak yang selama ini hidup secara normal dengan keluarganya turun ke jalan, dengan harapan supaya memperoleh dana proyek pembinaan anak jalanan di rumah singgah. Kondisi ini dimanfaatkan oleh sebagian LSM/Yayasan yang membina rumah singgah untuk 
memenuhi target jumlah anak yang ditetapkan proyek rumah singgah dari pemerintah. Kekhasan kondisi geografis, sosial budaya, ekonomi, latar belakang anak jalanan serta karakteristik anak secara pribadi kurang menjadi prioritas dalam pembinaan di rumah singgah.

Keberhasilan dalam pemberdayaan anak serta orang tua yang sebagian besar masyarakat Minangkabau di sebagian rumah singgah tidak menunjukkan hasil yang mengembirakan. Pola pembinaan menggunakan acuan yang seragam yang ditetapkan secara baku oleh Departemen Sosial. Keterlibatan pemuka masyarakat dalam pembinaan anak jalanan di rumah singgah, seperti : Alim Ulama, Cadiak Pandai dan Niniak Mamak kurang menjadi prioritas di Sumatera Barat. Begitu juga keterlibatan RT/RW, Lurah/Walinagari kurang terlihat memberian sumbangan dalam penguatan keluarga untuk mengatasi anak jalanan di Sumatera Barat. Perkembangan pembinaan anak jalanan yang dilakukan sebagian rumah singgah dikelola LSM/Yayasan kurang terpantau secara baik, karena sebagian laporan dilakukan untuk memenuhi kebutuhan proyek belaka. Pekerja sosial dalam melakukan pendampingan terhadap anak jalanan kurang tersaring serta dimonitoring kinerjanya secara baik oleh masyarakat, yang pada gilirannya membuahkan hasil yang kurang memuaskan terhadap pembinaan anak jalanan di rumah singgah.

Berdasarkan fenomena tersebut di atas, ditemukan usaha-usaha pembinaan terhadap anak jalanan belum menampakkan hasil sesuai dengan target yang diharapkan. Sehubungan dengan hal itu, menarik ditelusuri lebih lanjut melalui tulisan ini bagaimana relasi pekerja sosial dalam pembinaan anak jalanan melalui rumah singgah. Pengungkapan pembinaan anak jalanan melalui rumah singgah di 
bermanfaat dalam peningkatan peranserta rumah singgah untuk pembinaan anak jalanan mencapai kemandiriannya secara optimal.

\section{B. Karakteristik Anak Jalanan dan Perkembangan Kemadiriannya}

Anak jalanan yang dibina di rumah rumah selama ini memiliki karakteristik : (1) berusia 6-18 tahun, (2) berjenis kelamin laki-laki dan perempuan, (3) tinggal maupun tidak dengan orang tuanya, (4) masih bersekolah maupun putus sekolah, (5) mempunyai pekerjaan secara kontiniu maupun sambilan di jalan (Depsos, 1999:3).

Sehubungan dengan uraian tersebut, Depsos dan UNDP (1997) membagi anak jalanan atas:

1. Anak jalanan yang hidup di jalanan, dengan karakteristik : (a) telah pustus hubungan dengan orang tua, (b ) berada di jalanan seharian, 8-10 jam untuk bekerja dan sisanya untuk mengelandang dan tidur, (c) bertempat tinggal di jalan dan tidur di sembarang tempat, seperti : di emper toko, kolong jembatan, taman, terminal, stasiun dan lain-lain, (d) tidak bersekolah, (e) pekerjaan pada umumnya adalah mengamet, mengemis dan pemulung dan serabutan (melakukan apa saja yang hasilnya digunakan untuk memenuhi kebutuhan sendiri, (f) rata-rata berusia 14 thun.

2. Anak jalanan bekerja di jalan, dengan karakteristik : (a) berhubungan secara tidak teratur dengan orang tua, pulang ke orang tua secara priodik, (b) berada di jalan 812 jam untuk bekerja, sebagian mencapai 16 jam, (c) bertempat tinggal dengan cara mengontrak bersama teman/sendiri, mengikuti orang tuanya atau tempat kerjanya di jalan, (d) tempat kerja mereka umumnya di lingkungan kumuh yang terdiri dari orang-orang berasal dari daerah yang sama, (e) tidak bersekolah, (f) 
pekerjaan mereka umumnya mengasong, menjual koran, mencuci bis, memulung sampah, menyemir sepatu dan sebagainya serta rata-rata usianya 16 tahun.

3. Anak jalanan yang birusia 16 tahun, dengan karakteristik : (1) terdiri dari anak yang sudah putus hubungan dan berhubungan secara tidak teratur dengan orang tua, (2) berada di jalanan 8-24 jam, kadang hanya beberapa jam, kadang beberapa hari di jalanan, (3) tempat tinggal dan tidur mereka kadang-kadang di rumah orang tuanya, kadang-kadang di jalanan, (4) mereka telah tamat SD atau SLTP namun sudah tidak bersekolah lagi, (5) pekerjaan mereka biasanya tidak tetap serta (6) rata-rata usia mereka adalah 16 tahun.

Apabila ditinjau dari segi usia, anak jalanan yang berusia 6-18 tahun tersebut sedang menjalani periode perkembangan masa anak dan remaja yang memiliki perkembangan kemandirian berbeda satu dengan lainnya. Perkembangan kemandirian anak jalanan selama pembinaan melalui rumah singgah sangat ditentukan oleh relasi anak dengan pekerja social di rumah singgah. Kemandirian merupakan keadaan kepribadian individu yang ditunjukkan oleh adanya kesanggupan mengatasi sesuatu problem atau tugas secara memandiri.

Kemandirian yang dimiliki jalanan mengalami perubahan sesuai dengan perkembangan fisik dan psikisnya. Awal kehidupan sampai akhir masa bayi (usia 2 tahun) individu tergantung dengan bantuan orang lain terutama dalam pemenuhan kebutuhan biologis serta perawatan orang tua. Usia $2-3$ tahun individu sudah mencoba melatih dirinya sendiri dengan mengerjakan sesuatu menurut cara yang dipilihnya. Individu mulai sadar akan diri serta kesanggupannya akan tetapi tetap menyadari hal-hal tertentu tergantung dengan orang tuanya. Individu 
mempertahankan ketergantungannya karena ia takut kehilangan orang tuanya. Dalam kondisi ini relasi orang tua dengan anak mempegaruhi perkembangan kemandiriannya. Apabila individu memperoleh hukuman atau tidak memberi kesempatan melakukan apa yang diinginkannya maka ia cenderung tumbuh menjadi agresif. Apabila ia mendapat kasih sayang berlebihan atau terlalu dilindunggi akan tumbuh menjadi anak yang manja dan sangat tergantung dengan orang lain.

Usia 4 tahun, individu menunjukkan keinginan bertingkah laku seperti orang dewasa. Individu meniru apa yang dilakukan orang tuanya Kesanggupan dan kehangat orang tua meningkatkan kemungkinan anak meniru tingkah laku orang tua. Kehangat ayah akan mempegaruhi anak laki-laki, sedangkan kehangatan ibu mempegaruhi anak perempuan dalam periode peniruannya. Proses belajar bertingkah laku dan bersikap serta mentransfer nilai-nilai yang dimiliki orang tua disebut sebagai identifikasi. Identifikasi akan mempegaruhi perkembangan motivasi anak untuk mandiri dan berprestasi. Pola kemandirian yang sudah terbentuk sebelumnya akan terus berkembang dan sangat tergantung oleh dorongan orang tua serta orang dewasa lainnya. Apabila individu berhasil melakukan sesuatu secara mandiri, sebaiknya orang tua memberikan sesegera mungkin hadiah dalam bentuk pujian, ciuman atau pelukan, sehinga mereka akan cenderung mengulang kembali tingkah laku tersebut.

Setelah usia 5-7 tahun individu belum dapat menghadapi semua problem atau tugas dalam lingkungannya secara penuh. Ia mempunyai kemampuan terbatas sesuai dengan kematangan emosi, intelegensi dan fungsi motoriknya. Keadaan emosi yang menonjol pada usia 5-7 tahun adalah rasa takut bersumber atas penolakan orang tua, 
guru dan teman-temannya. Sedangkan intelgensi anak usia 5-7 tahun menurut Piaget (1989) berada tahap pre operasional (2-7 tahun). Masa ini terbentuk pemikiran simbolik ditandai dengan berkembangnya kemampuan berbahasa. Pemikiran berpusat pada diri sendiri atau ego sentris dan rangsangan kongkrik lebih mudah diterima dari pada rangsangan abstrak. Mereka sudah mampu memecahkan problem senderhana secara logis. Keadan motorik anak pada usia 5-7 tahun pada umumnya sudah mampu melakukan kegiatan sederhana. Keadaan ini memungkinkan untuk melatih anak dengan beberapa keterampilan sederhana. Setelah umur 4 tahun biasanya orang tua mempersiapkan anak memasuki sekolah. Selama berada di luar rumah mereka belajar secara mandiri mengurus diri sendiri. Pada usia ini individu seharusnya menguasai tingkah laku senderha, seperti makan, tidur, menjaga kebersihan diri. Pekerja social perlu memahami kondisi perkembangan anak jalanan pada usia ini, apabila menyampaikan informasi dilakukan secara kongkrit dengan menggunakan media atau contoh langsung dalam kehidupan sehari-hari.

Perkembangan kemandirian anak jalanan pada usia selanjutnya sangat ditentukan oleh proses belajar melalui latihan peniruan tingkah laku orang tua atau orang dewasa lainya, seperti pekerja sosial. Anak seharusnya mendapat dorongan dari orang tua atau pekerja sosial untuk mandiri, sehingga mereka memiliki pengetahuan tentang cara-cara sesuatu yang dapat diterima lingkungan.

Sehubungan dengan hal itu, situasi hubungan anak jalanan dengan orang tua dan pekerja sosial sangat menentukan perkembangan kemandirian anak. Sejak dari lahir individu telah memiliki ikatan kasih sayang dengan ibu atau dengan salah satu figus ibu. Ikatan tersebut terbentuk melalui perawatan dan pengasuhan anak sehari- 
hari. Situasi hubungan orang tua atau pekerja sosial sangat menentukan pengembangan kemandirian.

Beller (1989) mengemukakan gejala-gejela yang menunjukkan seseorang mandiri, yaitu: (1) mempunyai inisiatif, (2) berusaha mengatasi rintangan, (3) mencoba menyelesaikan rintangan, (4) mencoba menyelesaikan pekerjaan, (5) memperoleh kepusasan dari apa yang telah dilakukannya, (6) melaksanakan sendiri tugas-tugas rutin. Sedangkan Hendry C. Lingdren (1989) menjelaskan kemandirian dapat diperoleh apabila anak sudah memiliki kemampuan untuk melakukan sesuatu secara otonom. Artinya sudah mampu mengarahkan pikiran dan tindakannya sendiri tanpa bergantung pada orang lain.

Kondisi kemandirian anak jalanan di Sumatera Barat memiliki kekhasan tersendiri dibandingkan dengan daerah lain, Firman dan Sandora (2004) melalui penelitian menemukan anak jalanan di Sumatera Barat memiliki : (1) rasa percaya diri, (2) tidak rendah diri (rasa malu) terhadap lingkungan dan masyarakatnya, (3) bertanggung jawab terhadap keluarga, serta (4) merasa terbuang dari keluarga.

\section{Relasi Pekerja Sosial selama Pembinaan Anak Jalanan di Rumah Singgah}

Rumah singgah didefinisikan sebagai suatu wahana yang dipersiapkan sebagai perantara antara anak jalanan dengan pihak-pihak yang akan membantu menyelesaikan masalah-masalah sosial dan menemukan alternatif pemenuhan kebutuhan hidupnya, (Pedoman Penyelenggaraan Pembinaan Anak jalanan melalui Rumah Singgah Depsos RI Direktorat Jenderal Bina Kesejahteraan Sosial RI, 1999).

Rumah singgah diibaratkan bagaikan sebuah keluarga, dimana pekerja sosial bertindak sebagai orang tua atau kakak bagi anak jalanan. Pekerja sosial di samping 
bekerja di rumah singgah, mereka juga bertugas mengunjungi anak ke jalanan tempat mereka beraktivitas sehari-hari. Kenyataan yang ditemui, tidak semua anak jalanan mampir ke rumah singgah secara kontiniu. Kondisi ini mengakibatkan proses perubahan yang diharapkan dari anak jalanan mengalami hambatan. Bagi anak jalan yang datang secara rutin ke rumah singgah pembinaan dari pekerja social sesuai dengan program yang telah digariskan.

Anak jalanan berhubungan dengan pekerja social di rumah singah didasari oleh motif-motif tertentu. Thibault dan Kelley (Rachamat, 1997) dalam teori pertukaran social menjelaskan seseorang melakukan hubungan secara sukarela dan bertahan dalam hubungan tersebut selama memuaskan ditinjauh dari ganajaran yang diperoleh dibandingkan dengan biaya yang dikeluarkan dari hubungan tersebut.

Ganjaran merupakan nilai positif yang diperoleh anak jalanan melalui hubungan social dengan pekerja social di rumah singgah. Ganjaran yang mungkin diperoleh anak jalanan dari proses hubungan social tersebut, adalah : berupa uang, penerimaan social, informasi, cinta, barang, jasa, pengakuan social dan status. Sedangkan cost atau biaya merupakan akibat negatif yang dikeluarakan anak jalanan melalui hubungan sosial dengan pekerja social di rumah singggah. Biaya dalam hubungan social dapat berupa waktu, konflik serta kecemasan, keruntuhan harga diri, tenaga terlampau banyak dari kondisi lain yang dapat menimbulkan efek yang tidak menyenangkan.

Kelangsungan hubungan sosial antara pekerja social dengan anak jalanan ditentukan oleh perbandingan antara ganjaran yang diperoleh serta cost yang harus dikeluarkan untuk hubungan tersebut. Seseorang anak jalannan tidak segan segan 
menghabiskan waktu tenaga serta harga diri untuk mendapatkan pengalaman, keterampilan agar perbaikan kualitas hidupnya di masa mendatang. Apabila pengalaman, keterampilan yang diperoleh sesuai dengan tenaga, waktu dan harapan yang diinginkan terwujud maka hubungan tersebut akan bertahan. Apabila cost atau biaya yang dikeluarkan anak jalanan lebih besar dari reward atau ganjaran diperoleh dari sesesuatu hubungan dengan pengelola rumah singgah akan terjadi konflik yang mengarah kepada pemutusan hubungan social.

Sehubungan dengan hal itu, pekerja social di rumah singgah dalam pemberian pelayanan terhadap anak jalanan perlu mengidentifikasi minat, atau bakat dan motifmotif anak jalanan yang dibinanya mengigat berfariasinya karakteristik anak jalan. Pekerja social di rumah singgah dituntut memperhatikan anak jalanan secara individual dan kelompok beserta keunikan mereka masing-masing.

Apabila ditinjau dari segi umur yang menjadi sasaran binaan rumah singgah 6-18 tahun yang berada dalam periode perkembangan : umur 6/7 tahun sampai dengan 12 / 13 tahun merupakan periode anak akhir (late childhood) 11/12 tahun sampai dengan $15 / 6$ tahun periode pubertas, 11/12 tahun sampai dengan 15/16 tahun periode pubertas dan 13/14 tahun sampai dengan 18/21 tahun periode remaja.

Anak jalanan yang berada ke tiga periode perkembangan tersebut mempunyai karakteristik dan tugas perkembangan berbeda. Periode anak akhir dimulai sejak awal memasuki sekolah dasar dan berakhir ketika mereka mengalami kematangan seksual. Periode ini sering disebut periode anak sekolah, sebab periode ini mulai memasuki sekolah untuk mempelajari ilmu pengetahuan sebagai bekal kehidupan kelak. Di samping diistilahkan periode anak sekolah, periode ini sering juga disebut dengan 
periode usia berkelompok (gang age). Pada periode ini anak mulai berusaha menjadi anggota kelompok yang biasanya dengan jenis kelamin yang sama.

Havigurst menjelaskan tugas perkembangan yang harus mereka jalani pada periode anak sekolah adalah : (1) mengembangkan kemampuan motorik baik yang menggunakan otot halus (misalnya : menulis, menggambar, keterampilanketerampilan khusus ) dan otot kasar (seperti olah raga dan permainan), (2) makin mengembangkan konsep-konsep tentang lingkungan sekeliling, (3) mengembangkan tingkah laku moral dan menerima nilai lingkungan, (4) belajar bekerja sama dengan teman sebaya, (5) belajar memainkan peran sesuai dengan jenis kelamin, (6) belajar mengendalikan reaksi-reaksi emosional sesuai denegan harapan lingkungan social serta belajar menjadi individu yang mampu berdiri sendiri.

Sedangkan pada peride pubertas merupakan periode remaja awal yang ditandai dengan perubahan penampilan fisik dan fungsi fisiologi. Berlangsungnya periode pubertas ini singkat, yaitu 2-4 tahun dan karakteristik lain periode ini adalah pertumbuhan sangat cepat, Tugas perkembangan yang harus dijalani masa ini, adalah : (1) menerima perubahan tubuh yang dialami, (2) menerima peran sesuai dengan jenis kelamin menuju kearah kedewasaan. Usia 13/14 - 18/21 merupakan perioede remaja yang didahului oleh periode pubertas. Periode pubertas merupakan bagian dari periode remaja yang dititik beratkan kepada kematangan seksual, sedangkan periode remaja meliputi semua perubahan fisik dan psikis menuju kearah kedewasaan.

Havigurst menejelaskan tugas perkembangan yang harus dijalani remaja adalah : (1) menerima keadaan diri dan berperan sesuai dengan jenis kelamin , (2) membentuk hubungan dengan teman sebaya secara dewasa, (3) mengembangkan 
kemampuan berdiri sendiri baik secara emosional maupun ekonomi, (4) mengembangkan tanggung jawab social, (5) mengembangkan kemampuan dan keterampilan intelektual untuk hidup bermasyarakat dan masa depan dalam bidang pekerjaan atau pendidikan, (6) mempersiapkan diri dalam hidup berkeluarga serta (7) menciptakan nilai-nilai kedewasaan.

Pemeliharaan dan memperteguh hubungan antara anak jalanan dengan pekerja social di rumah singgah memerlukan tindakan tertentu untuk mengembalikan keseimbangan. Rachmat (1990) menjelaskan empat factor yang amat penting dalam memelihara keseimbangan hubungan, yaitu :

(1) keakraban, merupakan kebutuhan akan kasih sayang. Hubungan antar pribadi akan terpelihara apabila anak jalanan dengan pengelola rumah singgah sepakat menetapkan tingkat keakraban yang telah terbina.

(2) kesepakatan siapa yang akan mengontrol siapa dan bilamana. Jika dua orang mengambil pendapat berbeda sebelum mengambil kesepakatan siapa yang harus berbicara lebih banyak dan siapa menentukan dan dominan akan terjadi konflik, karena masing-masing mau berkuasa dan tidak ada mau mengalah,

(3) ketepatan respon, artinya respon anak jalanan harus diikuti oleh respon pekerja social yang sesuai. Pertanyaan harus disambut dengan jawaban, lelucon dengan tertawa dan sebagai. Respon biasanya berkenaan dengan pesan-pesan verbal dan non verbal. Jika pembicaan serius dari seseorang dijawab dengan main-main, ungkapan serius dijawab dengan olok-olok maka hubungan antar pribadi akan mengalami keretakan. Respon yang ditampilkan individu dalam hubungan social terasebut dapat dikategorikan ke dalam respon konfirmasi dan 
diskonfirmnasi. Respon konfirmasi akan memperteguh hubungan atar peribadi, misalnya dengan memberikan pengakuaan perasaan positif, respon meminta keterangan, respon setuju, sedangkan respon yang bersifat diskonformasi merusak hubungan natar pribadi, misalnya dengan memberikan respon sekilas, respon kosong, respon yang tidak relevan, respon kontradiktif dan sebagainya.

(4) keserasian suasana emosional ketika berlangsungnya hubungan. Jika seseorang berinteraksi dengan seseorang dan individu lainnya dalam suasana emosinal yang berbeda mamak interaksi tersebut tidak akan stabil dan besar kemungkinan salah satu fihak akan mengakhiri hubungan atau merubah suasana emosional yang sedang dirasakannya.

Kedangkalan hubungan pekerja social dengan anak jalanan di rumah singgah disinyalir bersumber dari kurang terbinanya hubungan interpersonal dengan baik. Kondisi ini menyebabkan rumah singgah tidak optimal dalam membina anak jalanan, walaupun rumah singgah telah memiliki pola pembinaan tersendiri. Pola pembinaan yang dilaksanakan di rumah singgah terdiri dari pola pembinaan pendidikan berorientasi kepada : (1) ilmu pengetahuan, (2) mata pencarian, dan (3) moral dan agama. Keberhasilan pembinaan anak jalanan ditentukan oleh kemampuan dan cara rumah singgah melaksanakan tugas yang dibebankan kepadanya untuk mengasuh anak jalanan.

Sandora (2003) mengungkapkan anak jalanan di Sumatera Barat relatif berpendidikan rendah dan animo mengikuti pendidikan juga lemah. Usaha rumah singgah mengatasi kendala tersebut, adalah memberikan bea siswa kepada anak jalanan yang masih sekolah. Selain itu rumah singgah memberikan bantuan alat-alat 
sekolah, seperti: buku pelajaran, alat tulis dan lain sebagainya. Sedangkan pelaksanaan pendidikan berorientasi pada mata pencarian rumah singgah memberi kesempatan kepada anak jalanan menetapkan jenis latihan keterampilan yang ingin diikuti dalam rangka menunjang aktivitas sehari-hari dan rumah singgah juga melaksanakan program penambahan modal usaha. Selanjutnya anak jalanan juga di ajar agama, etika dan sopan santun. Menunjang program pembinaan rohani terhadap anak jalanan, rumah singgah mempersiapkan sarana dan prasarana dalam menjalankan ibadah.

Rumah singgah dalam membina anak jalanan di Sumatera Barat menemukan berbagai kendala. Firman dan Sandora (2004) mengungkapkan selama melaksanakan pembinaan dan pemberdayaan terhadap anak jalanan beberapa hambatan ditemui oleh Rumah Singgah, yaitu : (1) sulitnya mencari tenaga pekerja sosial yang professional, hal ini dipengaruhi oleh : (a) jumlah pekerja sosial yang profesional sangat terbatas, (b) tugas dan tanggung jawab seorang pekerja sosial sangat berat, (c) minimnya tunjangan hidup bagi seorang pekerja sosial, (d) enggannya masyarakat berbaur dengan anak jalanan, hal ini dikarenakan masih banyaknya masyarakat yang berpandangan negatif terhadap anak jalanan. (e) besarnya resiko menjadi seorang pekerja sosial pada rumah singgah. Hal ini dimungkinkan karena masih banyak orang tua anak jalanan yang marah ketika anaknya diajak bergabung dengan rumah singgah, karena dengan bergabungnya anak jalanan dengan rumah singgah pendapatan anak akan berkurang, secara otomatis akan mengurangi penghasilan orang tua yang semata-mata mengharapkan dari anaknya, (2) dana pengelolaan rumah singgah 
terbatas, (3) kurangnya partisipasi masyarakat dalam pembinaan Anak Jalanan, (4) salah persepsi terhadap Rumah Singgah.

Masyarakat merasa asing melihat pembinaan anak jalanan melalui rumah singgah dan tidak jarang kurang mendapat dukungan selama proses pembinaan. Sebagian anak jalanan yang dibina satu rumah singgah dibina juga oleh rumah singgah lainnya. Keterlibatan tokoh masyarakat, RT/RW dan pemerintahan Nagari dalam pembinaan sangat terbatas sekali. Pembinaan terhadap anak jalanan kurang berkelanjutan serta terlepas dari struktur kekerabatan masyarakat setempat. Keterlepasan pola pembinaan anak jalanan dari kondisi sosial budaya masyarakat setempat merupakan salah satu hambatan yang dialami pekerja sosial dalam pembinaan anak jalanan.

\section{Penutup}

\section{Simpulan}

Berdasarkan uraian yang telah dipaparkan terdahulu, dapat disimpulkan sebagai berikut :

1. Pembinaan anak jalanan memerlukan pendekatan secara pribadi dan kelompok sesuai dengan keunikannya, mengigat karakteristika anak jalanan bervariasi baik dari segi usia, latar belakang keluarga, pendidikan, penyebab menjadi anak jalanan.

2. Perkembangan kemandiriana nak jalanan di rumah singgah sangat ditentukan kualitas relasi antara anak jalanan dengan pekerja sosial

3. Relasi antara pekerja sosial di rumah singgah akan bermakna bagi anak jalanan apabila melalui proses relasi tersebut sudah dipetik hasil berupa keterampilan, 
pengetahuan, dukungan social, penerimaan social, hadiah, uang dan sebagainya untuk perbaikan kualitas kehidupan mereka di masa datang.

\section{Saran}

1. Perlindungan dan pendidikan yang sudah disediakan rumah singgah yang dilaksanakan Lembaga Sosial Kemasyarakat (LSK) cenderung kurang dimanfaatkan oleh sebagian anak jalanan. Hubungan LSK dengan Dinas Sosial perlu ditingkatkan dalam penyusunan, pelaksanaan, monitoring dan penilaian program pembinaan sesuai dengan kebutuhan dan karakteristik anak jalanan pada masing-masing lokasi dan daerah.

2. Pembinaan anak jalanan melalui rumah singgah ditemukan memisahkan anak jalanan dari masyararakat dimana mereka berdomisili. Kondisi ini tidak jarang menyebakan meningkatnya jumlah anak turun ke jalan. Dinas social, Binsospora, BPM serta Biro Pemerintahan Nagari dirasa perlu mengembangkan pembinaan anak jalanan berbasis Nagari/Lurah, Jorong/RW/RT, melalui program dan sistim pemberdayaan masyarakat yang berwawasan budaya.

3. Mengurangi serta menghilangkan bentuk dan jenis perlakuan salah terhadap anak jalanan dirasa perlu adanya sosialisasi tentang hak-hak anak baik bagi orang tua maupun oleh masyarakat sehingga masyarakat dan orang tua bisa menempatkan anak pada posisi yang sepantasnya bagi anak. 


\section{DAFTAR KEPUSTAKAAN}

Afrizal (1999) : Laporan Hasil Pemetaan dan Survei Anak Jalanan Di Kota Padang. Padang : Kanwil Depsos Sumbar dan PKPM Unika Atmajaya.

Baihaqi, MIF. (1998). Anak Indonesia Teraniaya. Bandung: Remaja Rosdakarya.

Childhope (1989) : The Street Children of Asia: A Profile. Unicef.

Departemen Sosial RI (1997) : Petunjuk Teknis Kemitraan Departemen Sosial dengan Lembaga Sosial Kemasyarakatan, Jakarta : Direktorat Jenderal Bina Kesejahteraan Sosial.

(1999) : Petunjuk Teknis Pembinaan Kesejahteraan Sosial Anak Jalanan. Jakarta : Direktorat Jenderal Bina Kesejahteraan Sosial.

Firman dan Elisna Sandora (2004) : Efektifitas Pembinaan Anak Jalanan Melalui Rumah Singgah. Padang: Balitbang Propinsi Sumatera Barat.

Fatimah, Nyayu. (2001). Anak Jalanan: Fenomena Sosial Perkotaan. Makalah pada simposium dan lokakarya internasional II di Padang. Tanggal 18-21 Juli 2001.

Gautama, Candra. (2000). Konvensi Hak Anak. Jakarta: Lembaga Studi Pers \& Pembangunan.

Hurlock,Elizabeth B (1999) : Child Development. Tokyo : Mc Graw Hill Koga Kusha,Ltd

Ishardjiati, Eka. Anak jalanan dan penanggulangannya melalui rumah singgah. Dinamika sosial. Vol 72. 1999. Kanwil Departemen Sosial Propinsi Sumatera Barat.

Irwanto (1998). Pekerja Anak Di Tiga Kota Besar: Jakarta, Surabaya, Medan. Jakarta: Pusat Penelitian UNIKA Atmajaya.

Joni, Muhammad dan Tanamas. (1999). Aspek hukum perlindungan anak dalam perspektif konvensi hak anak. Bandung : Citra Adityabakti.

Kanwil Departemen Sosial Propinsi Sumatera Barat. (1999). Laporan penelitian pemetaan dan survei sosial anak jalanan di Kota Padang. Padang : Kanwil Depsos Sumbar

Kartono, Kartini. (1984). Patologi sosial I. Jakarta: Rajawali Press. 
Koentjaraningrat. (1997). Pengantar antropologi pokok-pokok etnografi II. Jakarta: Rineka Cipta.

Media Informasi Penelitian Kesejahteraan Sosial No. 156. (1998). Balai Besar Penelitian dan Pengembangan Pelayanan Kesejahteraan Sosial. Yogyakarta.

Moleong, Lexy. (1989). Metodologi penelitian kualitatif. Bandung: Remaja Rosdakarya.

Redaksi. Penanganan anak jalanan harus manusiawi. Republika. Sabtu 7 November 1998.

Sandora, Lisna (2003). Tesis, Perlakuan Salah yang dialami Anak Jalanan di Kota Padang. UNP. Padang

Sutaat. Studi kasus anak nakal pada pran Wisma Handayani Jakarta. Media Informatika No. 33. 1993. hal. 10-28. Jakarta: Badan Penelitian dan Pengembangan Sosial, Depsos.

Tamrizal Dt. Gadang. Populasi Anak Jalanan di Kota Padang Telah Meningkat. Haluan. Sabtu. 30 Januari 2003.

Tunggal, Hadi Setia. (2000). Konvensi hak-hak anak (convention on the right of the child). Jakarta: Harvarindo.

Unicef. (1989). Convention on the rights of the child. New York.

Zulkifli. (1986). Psikologi perkembangan. Bandung: Remaja Rosdakarya.

Welly, Farida. Pola Pembinaan Anak Jalanan; Studi Kasus pada Rumah Singgah Srikandi Kota Padang. Humanus. Vol. V. No. 1 Th. 2002 
